Western University Scholarship@Western

$10-27-2014$

\title{
Euvolemia in hemodialysis patients: a potentially dangerous goal?
}

Shih-Han S Huang

Western University,shuang45@uwo.ca

Guido Filler

Western University, Guido.Filler@lhsc.on.ca

Robert Lindsay

Western University, robert.lindsay@lhsc.on.ca

Chris W McIntyre

Western University, cmcint48@uwo.ca

Follow this and additional works at: https://ir.lib.uwo.ca/biophysicspub

Part of the Medical Biophysics Commons

Citation of this paper:

Huang, Shih-Han S; Filler, Guido; Lindsay, Robert; and McIntyre, Chris W, "Euvolemia in hemodialysis patients: a potentially dangerous goal?" (2014). Medical Biophysics Publications. 16.

https://ir.lib.uwo.ca/biophysicspub/16 


\title{
Euvolemia in Hemodialysis Patients: A Potentially Dangerous Goal?
}

\author{
Shih-Han S. Huang, ${ }^{\star} \dagger \ddagger$ Guido Filler, ${ }^{\star} \ddagger$ Robert Lindsay, ${ }^{\dagger} \dagger$ and Chris W. Mclntyre ${ }^{\star} \dagger \S$ \\ ${ }^{*}$ Department of Medicine, Division of Nephrology, Western University and London Health Sciences Centre, \\ London, Canada, †Department of Medical Biophysics, Western University, London, Canada, fDepartment \\ of Pediatrics, Western University, London, Canada, and §Department of Renal Medicine, Royal Derby \\ Hospital, NHS Foundation Trust, Derby, United Kingdom
}

\begin{abstract}
Dialysis patients have high mortality rate and the leading cause of death is cardiovascular disease. Uremic cardiomyopathy differs from that due to conventional atherosclerosis, where cardiovascular changes result in ineffective circulation and lead to tissue ischemia. Modern dialysis has significant limitations with fluid management probably the most challenging. Current evidence suggests that both volume overload and aggressive fluid removal can induce circulatory stress and multi-organ injury. Fur-
\end{abstract}

thermore, we do not have accurate volume assessment tools. As a result, targeting euvolemia might result in more harm than benefit with conventional hemodialysis therapy. Therefore, it might be time to consider a degree of permissive over-hydration until we have better tools to both determine ideal weight and improve current renal replacement therapy so that the process of achieving it is not so fraught with the current dangers.
Despite continuous advancements in dialysis therapies, the mortality rate of dialysis patients remains high at $60 \%$ after 5 years of dialysis treatment $(1,2)$. The leading causes of death in dialysis patients are cardiovascular in origin. The pathophysiology of these cardiovascular comorbidities differs from those associate with conventional atherosclerosis. These differences are structural (vascular calcification is medial rather than intimal), biochemical (calcium-phosphate products are increased) and functional (congestive heart failure and contractile dysfunction are common). As a result, treating traditional cardiovascular risk factors has not significantly improved survival in patients with chronic kidney disease (CKD) (3-6).

The development of uremic cardiomyopathy is likely multifactorial. The uremia itself may cause inflammation, congestive heart failure and volume overload, which lead to cardiovascular remodeling and calcification $(7,8)$. For example, one of the products that accumulate in the state of uremia is fibroblast growth factor 23 (FGF23), a protein that

Address correspondence to: Dr. Shih-Han S Huang, 800 Commissioners Road East, Room A2-344, London, ON, Canada, N6A 5W9, or Tel.: 519-685-8066, Fax: 519-4884732, or e-mail: shuang45@uwo.ca.

Conflicts of interest: None.

Seminars in Dialysis-Vol 28, No 1 (January-February) 2015 pp. 1-5

DOI: $10.1111 /$ sdi. 12317

(C) 2014 Wiley Periodicals, Inc. is be markedly elevated in CKD stage 5. It is strongly associated with CKD patient survival, and may contribute to myocardial fibrosis (9). As a result, cardiovascular remodeling and calcification results in stiffening and ineffective macro- and micro-vascular circulation. These changes have primed patients for demand ischemia, and have impaired the ability for patients to tolerate fluid removal, which result in long-term volume overload. Furthermore, the volume overload commonly seen in CKD alone can also increase $\mathrm{TNF}-\alpha$, leading to inflammation, fibrosis, and cardiac dilation (10). By contrast, too much fluid removal can result in intradialytic injury leading to a reduction in residual renal function, which aggravates fluid accumulation. The aim of this review is to critically evaluate the common clinical goal of targeting euvolemia in dialysis patients.

\section{Volume Overload and Cardiovascular Outcomes}

Volume overload is common in dialysis patients. It is associated with increased cardiovascular morbidity and mortality (11). Extracellular fluid expansion is associated with left ventricular hypertrophy (LVH) and cardiac fibrosis $(12,13)$. Volume overload is also strongly associated with $\mathrm{LVH}$ and improving volume control can lead to left ventricular mass regression (14). For example, salt 
restriction resulted in a reduction in inter-dialytic weight gain and left ventricular mass without a change in pre-dialysis blood pressure (15). LVH and left ventricular dilation are associated with an increased rate of sudden cardiac death and other cardiovascular morbidity and mortality $(16,17)$. In contrast, a decrease in left ventricular mass over time is associated with lower rates of death and cardiovascular events $(16,18)$. It is therefore reasonable to assume that our aim should be to tightly control fluid status and to aggressively remove fluid in order to avoid volume overload in dialysis patients. Still, achieving a "true dry weight" in dialysis patients can be challenging and even impossible, and there may be a price to pay.

\section{The Challenge of Targeting Euvolemia}

\section{The Challenge of Achieving a Dry Weight in All Patients}

Dry weight is currently defined as "the lowest tolerated post-dialysis weight achieved with minimal signs or symptoms of hypo- or hypervolemia" (19). This definition is, however, incomplete. Some patients may meet the above definition but are in chronic volume overload because of intra-dialytic hypotension and/or symptoms related to dialysis and ultrafiltration. Intra-dialytic hypotension is common in dialysis patients (15-30\% of all dialysis treatments) and has proven to pose a clinical challenge (20). Intra-dialytic hypotension can result from hypovolemia, from an inadequate hemodynamic response from the sympathetic nervous system and a slow refilling rate, from autonomic dysfunction, or from underlying cardiac disease. Despite employing strategies to avoid intra-dialytic hypotension, patients may still experience these symptoms and may be unable to reach their set target weight.

\section{What is the Ideal Weight?}

There is currently no gold standard measurement for dry weight. Heavy water total body water measurement has been used to measure total body water, but it is costly and is not available in all centers (21). Other methods such as clinical assessment of dry weight by evaluating edema, blood pressure, jugular venous extension and/or biomarkers (such as B-type natriuretic peptide, the N-terminal pro-B-type natriuretic peptide and troponin) do not always correlate with volume overload $(22,23)$. For example, N-terminal pro-B-type level is influenced by the degree of renal impairment and by the underlying cardiovascular disease.

Measuring relative plasma volume through relative hematocrit concentration is another way of assessing dry weight. This method is incorporated in some hemodialysis machines and has shown some prognostic importance in dialysis outcomes (11). Nevertheless, the Crit-Line Intra-dialytic Monitoring Benefit Study showed increased mortality in patients who were dialyzed with blood volume monitoring (24).

Ultrasound measurement of the inferior vena cava has also been studied as an option for assessing dry weight, but it can only assess intravascular volume (25). It is therefore neither sensitive nor specific enough for volume overload and can be influenced by underlying heart failure. This drawback has impeded its routine use in clinical practice.

More recent studies have examined the application of bioimpedance spectroscopy to assess volume. This method measures resistance and reactance to determine total body water and to differentiate intracellular and extracellular fluid. A multi-frequency bioimpedance device such as the body composition monitor (BCM, Fresenius Medical Care, Bad Homburg, Germany) has shown some promising results (26-29). Still, this device has only been tested on a limited scale and cannot be used in certain patients. More research is required to determine which method is optimal for determining dry weight.

\section{The Negative Consequences of Large Volume Removal}

Studies have shown that residual renal function is an important prognostic marker for dialysis patients $(30,31)$. This is likely related to both fluid removal and uremic toxin clearance. Preserving residual renal function is an important goal. Researchers have identified several factors that can predict a decline in residual renal function. Of these, peritoneal dialysis is more adept at preserving residual renal function than hemodialysis, and intra-dialytic hypotension and episodes of dehydration are associated with a more rapid decline in residual renal function (32).

Myocardial stunning, left ventricular dysfunction from transient myocardial ischemia which persists after reperfusion, has been well described in the cardiology literature. Since patients with end-stage renal disease are prone to cardiac ischemia, the hemodynamic stress of hemodialysis may produce such stunning. Burton et al. showed that the myocardium of $67 \%$ of patients stunned during hemodialysis treatments (33). Repetitive stunning can lead to myocardial remodeling and fibrosis and a fixed reduction in cardiac function (34). Patients who have experienced 1 year of hemodialysis-associated myocardial stunning have a higher mortality rate than those hemodialysis patients who do not exhibit such stunning (35). It is not surprising that cardiac stunning during hemodialysis is associated with a reduction in intravascular volume and systolic blood pressure, which reduces myocardial perfusion, bringing about cardiac 
ischemia $(35,36)$. This reduction in blood perfusion can also take place in other organs, including the brain and gut (37).

\section{Clinical Dilemma}

With the above information in mind, the practicing nephrologist is presented with a clinical dilemma. A variety of constraints have led to shortened hemodialysis treatments at the same time as the dialysis population has become more at risk of hemodynamic instability during treatment; this has rendered chronic volume overload a considerable clinical challenge. Volume overload is associated with long-term cardiovascular complications in dialysis patients including a poor survival rate. In contrast, removing excessive fluid in an attempt to achieve a euvolemic state can also lead to poor patient outcomes in conventional thrice-weekly hemodialysis by evoking intra-dialytic hypotension, myocardial stunning and loss of residual renal function. It is likely that many patients would benefit from some volume reserve to avoid myocardial stunning and other organ ischemia.

Volume control in dialysis patients may, in fact, be somewhat analogous to blood glucose control in diabetic patients. Studies have shown that adequate blood glucose control reduces microvascular and/or macrovascular complications in diabetic patients (38). Yet targeting normal hemoglobin A1C by way of intense therapy can lead to a higher risk of hypoglycemic events and death (39). Similarly, we must avoid chronic excessive volume overload as well as symptomatic episodes of intravascular depletion in patients being treated with conventional 4-hour thrice-weekly hemodialysis. We may need to increase the target weights of at risk patients, acknowledging that they are above ideal values, to avoid hypotension and all its associated ill effects. The amount of this "permissive fluid" must be individualized, depending on the patient's underlying cardiovascular status and treatment tolerance.

\section{Fluid Management in Dialysis Patients}

Such a permissive increase in target weight should not be undertaken until every effort has been made to improve intradialytic hemodynamics. The value of increased treatment time is obvious as is the critical role of sodium balance for volume control. The value of reducing salt intake cannot be overemphasized; however, it requires patient adherence to a difficult diet. The commonplace dialysate sodium of $140 \mathrm{mmol} / \mathrm{l}$ is not optimal for all patients. When dialysate sodium concentration is higher than the pre-dialysis plasma sodium a positive diffusive sodium balance will occur requiring increased convective loss by ultrafiltration; inter-dialytic weight gain and volume overload will be exacerbated (40).
A patient's dialysate sodium concentration should be individualized based on pre-dialysis plasma sodium levels in order to avoid this positive diffusive sodium balance and volume overload. The ability to decrease sodium absorption from the gastrointestinal tract, using medications such as tenapanor (an inhibitor of the sodium-proton exchanger in the gastrointestinal tract and kidney) is an exciting development and may have some role in the future (41).

Another simple and effective intervention is to lower the temperature of the dialysate which reduces vascular dilatation and limits intra-dialytic hypotension and myocardial stunning. McIntyre et al. looked at the benefits of cooling the dialysate to $0.5^{\circ} \mathrm{C}$ below core temperature in 73 randomized patients; both groups (cooled and standard dialysate) were matched in their ultrafiltration volume (42). Dialysate cooling preserved left ventricular function, reduced myocardial stunning and lowered the risk of vascular injury to the brain.

Although peritoneal dialysis is a continuous therapy, it is also associated with a high rate of chronic volume overload and high cardiovascular morbidity which may, in part, be related to a large glucose load and chronic inflammation $(43,44)$. In contrast, hemodialysis patients who suffer from chronic volume overload may benefit from frequent and/or nocturnal hemodialysis which can reverse left ventricular hypertrophy, reduce left and right ventricular volume, and improve patient survival (45). The Frequent Hemodialysis Network Trials, the two largest randomized controlled studies comparing short-hour daily hemodialysis and nocturnal hemodialysis to thrice-weekly hemodialysis $(46,47)$, showed that increased hemodialysis frequency with or without an increase in duration may improve cardiovascular outcomes in dialysis patients. A change in frequency and/or duration may improve volume and hemodynamic control during and after the treatment.

\section{Conclusion}

Since the 1960s, dialysis has progressed from an experimental treatment to a mature therapy. Although effective for sustaining life, modern dialysis has significant limitations. Fluid management is challenging as a result of the non-physiologic nature of hemodialysis with its limited duration and frequency. Current evidence suggests that both volume overload and aggressive fluid removal can induce circulatory stress and multi-organ injury. Perhaps, targeting the "Holy Grail" of euvolemia results in more cardiovascular injury in this population than previously realized and is a factor in the poor patient outcomes with conventional hemodialysis therapy. At the current time, we do not have "continuous" hemodialysis therapy to avoid the demand ischemia of reaching the ideal fluid control. Is it 
time to consider some permissive over-hydration, to a level that prevents "removal stress" but is short of damaging overload? Future investigator-initiated research plus technical and clinical innovations are needed to develop better tools to assess volume status so that our goals are clear and to improve current renal replacement therapy so that achieving them are less problematic.

\section{Acknowledgments}

Dr. S. Huang has received a CIHR Vanier Salary Award.

\section{References}

1. Eknoyan G, Beck GJ, Cheung AK, Daugirdas JT, Greene T, Kusek JW, Allon M, Bailey J, Delmez JA, Depner TA, Dwyer JT, Levey AS, Levin NW, Milford E, Ornt DB, Rocco MV, Schulman G, Schwab SJ, Teehan BP, Toto R, Hemodialysis Study G: Effect of dialysis dose and membrane flux in maintenance hemodialysis. $N$ Engl $\mathrm{J}$ Med 347:2010-2019, 2002

2. Paniagua R, Amato D, Vonesh E, Correa-Rotter R, Ramos A, Moran J, Mujais S, Mexican Nephrology Collaborative Study G: Effects of increased peritoneal clearances on mortality rates in peritoneal dialysis: ADEMEX, a prospective, randomized, controlled trial. J Am Soc Nephrol 13:1307-1320, 2002

3. Wanner C, Krane V, Marz W, Olschewski M, Mann JF, Ruf G, Ritz E, German D, Dialysis Study I: Atorvastatin in patients with type 2 diabetes mellitus undergoing hemodialysis. N Engl J Med 353:238-248, 2005

4. Baigent C, Landray MJ, Reith C, Emberson J, Wheeler DC, Tomson C, Wanner C, Krane V, Cass A, Craig J, Neal B, Jiang L, Hooi LS, Levin A, Agodoa L, Gaziano M, Kasiske B, Walker R, Massy ZA, Feldt-Rasmussen B, Krairittichai U, Ophascharoensuk V, Fellstrom B, Holdaas H, Tesar V, Wiecek A, Grobbee D, de Zeeuw D, Gronhagen-Riska C, Dasgupta T, Lewis D, Herrington W, Mafham M, Majoni W, Wallendszus K, Grimm R, Pedersen T, Tobert J, Armitage J, Baxter A, Bray C, Chen Y, Chen Z, Hill M, Knott C, Parish S, Simpson D, Sleight P, Young A, Collins R, Investigators S: The effects of lowering LDL cholesterol with simvastatin plus ezetimibe in patients with chronic kidney disease (Study of Heart and Renal Protection): a randomised placebo-controlled trial. Lancet 377:2181-2192, 2011

5. Tonelli M, Muntner P, Lloyd A, Manns B, Klarenbach S, Pannu N, James M, Hemmelgarn B, Alberta Kidney Disease N: Association between LDL-C and risk of myocardial infarction in CKD. J Am Soc Nephrol 24:979-986, 2013

6. Fellstrom BC, Jardine AG, Schmieder RE, Holdaas H, Bannister K, Beutler J, Chae DW, Chevaile A, Cobbe SM, Gronhagen-Riska C, De Lima JJ, Lins R, Mayer G, McMahon AW, Parving HH, Remuzzi G, Samuelsson O, Sonkodi S, Sci D, Suleymanlar G, Tsakiris D, Tesar V, Todorov V, Wiecek A, Wuthrich RP, Gottlow M, Johnsson E, Zannad F, Group AS. Rosuvastatin and cardiovascular events in patients undergoing hemodialysis. N Engl J Med 360: 1395-1407, 2009

7. Demirci MS, Demirci C, Ozdogan O, Kircelli F, Akcicek F, Basci A, Ok E, Ozkahya M: Relations between malnutrition-inflammation-atherosclerosis and volume status. The usefulness of bioimpedance analysis in peritoneal dialysis patients. Nephrol Dial Transplant 26:1708-1716, 2011

8. Hung SC, Kuo KL, Peng CH, Wu CH, Lien YC, Wang YC, Tarng DC: Volume overload correlates with cardiovascular risk factors in patients with chronic kidney disease. Kidney Int 85:703-709, 2014

9. Chen Z, Chen X, Xie J, Ma X, Zhong F, Hou L, Ling H, Li X, Ren H, Chen N: Fibroblast growth factor 23 is a predictor of aortic artery calcification in maintenance hemodialysis patients. Ren Fail 35:660-666, 2013

10. Feldman AM, Combes A, Wagner D, Kadakomi T, Kubota T, Li YY, McTiernan C: The role of tumor necrosis factor in the pathophysiology of heart failure. J Am Coll Cardiol 35:537-544, 2000

11. Agarwal R: Hypervolemia is associated with increased mortality among hemodialysis patients. Hypertension 56:512-517, 2010

12. Agarwal R, Leehey DJ, Olsen SM, Dahl NV: Proteinuria induced by parenteral iron in chronic kidney disease-a comparative randomized controlled trial. Clin J Am Soc Nephrol 6:114-121, 2011

13. Ritz E: Left ventricular hypertrophy in renal disease: beyond preload and afterload. Kidney Int 75:771-773, 2009
14. Lindsay RM, Leitch R, Heidenheim AP, Kortas C, London Daily/ Nocturnal Hemodialysis S. The London Daily/Nocturnal Hemodialysis Study-study design, morbidity, and mortality results. Am J Kidney Dis 42: 5-12, 2003

15. Kayikcioglu M, Tumuklu M, Ozkahya M, Ozdogan O, Asci G, Duman S, Toz H, Can LH, Basci A, Ok E: The benefit of salt restriction in the treatment of end-stage renal disease by haemodialysis. Nephrol Dial Transplant 24:956-962, 2009

16. Zoccali C, Benedetto FA, Mallamaci F, Tripepi G, Giacone G, Stancanelli B, Cataliotti A, Malatino LS: Left ventricular mass monitoring in the follow-up of dialysis patients: prognostic value of left ventricular hypertrophy progression. Kidney Int 65:1492-1498, 2004

17. Zoccali C, Benedetto FA, Mallamaci F, Tripepi G, Giacone G, Cataliotti A, Seminara G, Stancanelli B, Malatino LS: Prognostic value of echocardiographic indicators of left ventricular systolic function in asymptomatic dialysis patients. J Am Soc Nephrol 15:1029-1037, 2004

18. London GM, Pannier B, Guerin AP, Blacher J, Marchais SJ, Darne B, Metivier F, Adda H, Safar ME: Alterations of left ventricular hypertrophy in and survival of patients receiving hemodialysis: followup of an interventional study. J Am Soc Nephrol 12:2759-2767, 2001

19. Sinha AD, Agarwal R: Can chronic volume overload be recognized and prevented in hemodialysis patients? The pitfalls of the clinical examination in assessing volume status. Semin Dial 22:480-482, 2009

20. Santos SF, Peixoto AJ, Perazella MA: How should we manage adverse intradialytic blood pressure changes? Adv Chronic Kidney Dis 19:158-165, 2012

21. Chan C, Smith D, Spanel P, McIntyre CW, Davies SJ: A non-invasive, on-line deuterium dilution technique for the measurement of total body water in haemodialysis patients. Nephrol Dial Transplant 23:2064-2070, 2008

22. Agarwal R, Andersen MJ, Pratt JH: On the importance of pedal edema in hemodialysis patients. Clin J Am Soc Nephrol 3:153-158, 2008

23. Wabel P, Moissl U, Chamney P, Jirka T, Machek P, Ponce P, Taborsky P, Tetta C, Velasco N, Vlasak J, Zaluska W, Wizemann V: Towards improved cardiovascular management: the necessity of combining blood pressure and fluid overload. Nephrol Dial Transplant 23:2965-2971, 2008

24. Reddan DN, Szczech LA, Hasselblad V, Lowrie EG, Lindsay RM, Himmelfarb J, Toto RD, Stivelman J, Winchester JF, Zillman LA, Califf RM, Owen WF Jr: Intradialytic blood volume monitoring in ambulatory hemodialysis patients: a randomized trial. J Am Soc Nephrol 16:2162-2169, 2005

25. Kraemer M, Rode C, Wizemann V: Detection limit of methods to assess fluid status changes in dialysis patients. Kidney Int 69:1609-1620, 2006

26. Van Biesen W, Williams JD, Covic AC, Fan S, Claes K, Lichodziejewska-Niemierko M, Verger C, Steiger J, Schoder V, Wabel P, Gauly A, Himmele R, Euro BCMSG: Fluid status in peritoneal dialysis patients: the European Body Composition Monitoring (EuroBCM) study cohort. PLOS ONE 6:e17148, 2011

27. Devolder I, Verleysen A, Vijt D, Vanholder R, Van Biesen W: Body composition, hydration, and related parameters in hemodialysis versus peritoneal dialysis patients. Perit Dial Int 30:208-214, 2010

28. Machek P, Jirka T, Moissl U, Chamney P, Wabel P: Guided optimization of fluid status in haemodialysis patients. Nephrol Dial Transplant 25:538-544, 2010

29. Wizemann V, Wabel P, Chamney P, Zaluska W, Moissl U, Rode C, Malecka-Masalska T, Marcelli D: The mortality risk of overhydration in haemodialysis patients. Nephrol Dial Transplant 24:1574-1579, 2009

30. Bargman JM, Thorpe KE, Churchill DN, Group CPDS: Relative contribution of residual renal function and peritoneal clearance to adequacy of dialysis: a reanalysis of the CANUSA study. $J$ Am Soc Nephrol 12:2158-2162, 2001

31. Termorshuizen F, Dekker FW, van Manen JG, Korevaar JC, Boeschoten EW, Krediet RT, Group NS: Relative contribution of residual renal function and different measures of adequacy to survival in hemodialysis patients: an analysis of the Netherlands Cooperative Study on the Adequacy of Dialysis (NECOSAD)-2. J Am Soc Nephrol 15:1061-1070, 2004

32. Jansen MA, Hart AA, Korevaar JC, Dekker FW, Boeschoten EW, Krediet RT, Group NS: Predictors of the rate of decline of residual renal function in incident dialysis patients. Kidney Int 62:1046-1053, 2002

33. Burton JO, Korsheed S, Grundy BJ, McIntyre CW: Hemodialysisinduced left ventricular dysfunction is associated with an increase in ventricular arrhythmias. Ren Fail 30:701-709, 2008

34. Burton JO, Jefferies HJ, Selby NM, McIntyre CW: Hemodialysisinduced repetitive myocardial injury results in global and segmental reduction in systolic cardiac function. Clin J Am Soc Nephrol 4:1925-1931, 2009

35. Burton JO, Jefferies HJ, Selby NM, McIntyre CW: Hemodialysisinduced cardiac injury: determinants and associated outcomes. Clin $J$ Am Soc Nephrol 4:914-920, 2009 
36. McIntyre CW, Burton JO, Selby NM, Leccisotti L, Korsheed S, Baker CS, Camici PG: Hemodialysis-induced cardiac dysfunction is associated with an acute reduction in global and segmental myocardial blood flow. Clin J Am Soc Nephrol 3:19-26, 2008

37. McIntyre CW: Recurrent circulatory stress: the dark side of dialysis. Semin Dial 23:449-451, 2010

38. Holman RR, Paul SK, Bethel MA, Matthews DR, Neil HA: 10-year follow-up of intensive glucose control in type 2 diabetes. $N$ Engl $J$ Med 359:1577-1589, 2008

39. Action to Control Cardiovascular Risk in Diabetes Study G, Gerstein HC, Miller ME, Byington RP, Goff DC Jr, Bigger JT, Buse JB, Cushman WC, Genuth S, Ismail-Beigi F, Grimm RH Jr, Probstfield JL, Simons-Morton DG, Friedewald WT: Effects of intensive glucose lowering in type 2 diabetes. $N$ Engl J Med 358: 2545-2559, 2008

40. Flanigan $\mathbf{M}$ : Dialysate composition and hemodialysis hypertension. Semin Dial 17:279-283, 2004

41. Spencer AG, Labonte ED, Rosenbaum DP, Plato CF, Carreras CW, Leadbetter MR, Kozuka K, Kohler J, Koo-McCoy S, He L, Bell N, Tabora J, Joly KM, Navre M, Jacobs JW, Charmot D: Intestinal inhibition of the $\mathrm{Na}+\mathrm{H}+$ exchanger 3 prevents cardiorenal damage in rats and inhibits Na+ uptake in humans. Sci Transl Med 6:227ra236, 2014

42. Eldehni MT, Odudu A, McIntyre CW: Randomized clinical trial of dialysate cooling and effects on brain white matter. J Am Soc Nephrol. 2014 Sep 18. pii: ASN.2013101086. [Epub ahead of print]

43. Li PK, Chow KM: The clinical and epidemiological aspects of vascular mortality in chronic peritoneal dialysis patients. Perit Dial Int 25 (Suppl 3):S80-83, 2005

44. Krediet RT, Balafa O: Cardiovascular risk in the peritoneal dialysis patient. Nat Rev Nephrol 6:451-460, 2010

45. Culleton BF, Walsh M, Klarenbach SW, Mortis G, Scott-Douglas N, Quinn RR, Tonelli M, Donnelly S, Friedrich MG, Kumar A, Mahal- lati $\mathrm{H}$, Hemmelgarn BR, Manns BJ: Effect of frequent nocturnal hemodialysis vs conventional hemodialysis on left ventricular mass and quality of life: a randomized controlled trial. JAMA 298:1291-1299, 2007

46. Group FHNT, Chertow GM, Levin NW, Beck GJ, Depner TA, Eggers PW, Gassman JJ, Gorodetskaya I, Greene T, James S, Larive B, Lindsay RM, Mehta RL, Miller B, Ornt DB, Rajagopalan S, Rastogi A, Rocco MV, Schiller B, Sergeyeva O, Schulman G, Ting GO, Unruh ML, Star RA, Kliger AS: In-center hemodialysis six times per week versus three times per week. $N$ Engl J Med 363:2287-2300, 2010

47. Rocco MV, Lockridge RSJr ., Beck GJ, Eggers PW, Gassman JJ,

Greene T, Larive B, Chan CT, Chertow GM, Copland M, Hoy CD, Lindsay RM, Levin NW, Ornt DB, Pierratos A, Pipkin MF, Rajagopalan S, Stokes JB, Unruh ML, Star RA, Kliger AS, Frequent Hemodialysis Network Trial G, Kliger A, Eggers P, Briggs J, Hostetter T, Narva A, Star R, Augustine B, Mohr P, Beck G, Fu Z, Gassman J, Greene T, Daugirdas J, Hunsicker L, Larive B, Li M, Mackrell J, Wiggins K, Sherer S, Weiss B, Rajagopalan S, Sanz J, Dellagrottaglie S, Kariisa M, Tran T, West J, Unruh M, Keene R, Schlarb J, Chan C, McGrath-Chong M, Frome R, Higgins $\mathrm{H}$, Ke S, Mandaci $\mathrm{O}$, Owens C, Snell C, Eknoyan G, Appel L, Cheung A, Derse A, Kramer C, Geller N, Grimm R, Henderson L, Prichard S, Roecker E, Rocco M, Miller B, Riley J, Schuessler R, Lockridge R, Pipkin M, Peterson C, Hoy C, Fensterer A, Steigerwald D, Stokes J, Somers D, Hilkin A, Lilli K, Wallace W, Franzwa B, Waterman E, Chan C, McGrathChong M, Copland M, Levin A, Sioson L, Cabezon E, Kwan S, Roger D, Lindsay R, Suri R, Champagne J, Bullas R, Garg A, Mazzorato A, Spanner E, Rocco M, Burkart J, Moossavi S, Mauck V, Kaufman T, Pierratos A, Chan W, Regozo K, Kwok S: The effects of frequent nocturnal home hemodialysis: the Frequent Hemodialysis Network Nocturnal Trial. Kidney Int 80: 1080-1091, 2011 